\title{
Article
}

\section{Phylogeography of Hypomasticus copelandii (Teleostei, Anostomidae) Reveals Distinct Genetic Lineages along Atlantic Coastal Drainages of Eastern Brazil}

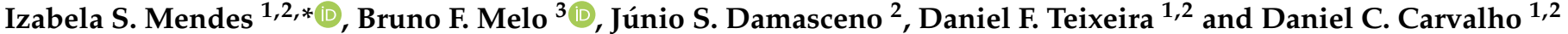 \\ 1 Post-Graduate Program in Genetics, Federal University of Minas Gerais, Belo Horizonte 31270-901, Brazil; \\ danielfonsecat@gmail.com (D.F.T.); carvalho.lgc@gmail.com (D.C.C.) \\ 2 Conservation Genetics Laboratory, Post-Graduate Program in Vertebrate Biology, Pontifical Catholic \\ University of Minas Gerais, PUC Minas, Belo Horizonte 30535-610, Brazil; jdamascenobh@gmail.com \\ 3 Department of Ichthyology, Division of Vertebrate Zoology, American Museum of Natural History, \\ New York, NY 10024, USA; bmelo@amnh.org \\ * Correspondence: izabelasantosmendes@hotmail.com
}

Citation: Mendes, I.S.; Melo, B.F.; Damasceno, J.S.; Teixeira, D.F.;

Carvalho, D.C. Phylogeography of Hypomasticus copelandii (Teleostei, Anostomidae) Reveals Distinct Genetic Lineages along Atlantic Coastal Drainages of Eastern Brazil Diversity 2022, 14, 29. https:// doi.org/10.3390/d14010029

Academic Editors: José Eustáquio Santos, Fabrício Rodrigues Dos Santos and Michael Wink

Received: 21 October 2021 Accepted: 18 November 2021 Published: 4 January 2022

Publisher's Note: MDPI stays neutral with regard to jurisdictional claims in published maps and institutional affiliations.

Copyright: (C) 2022 by the authors. Licensee MDPI, Basel, Switzerland. This article is an open access article distributed under the terms and conditions of the Creative Commons Attribution (CC BY) license (https:// creativecommons.org/licenses/by/ $4.0 /)$.

\begin{abstract}
Hypomasticus copelandii is a Neotropical freshwater fish widely distributed across coastal drainages of southeastern Brazil, a highly impacted region of South America. The interspecific phylogenetic relationships within the genus and the taxonomic status of the species remain uncertain. Using two mitochondrial and one nuclear locus, we performed a phylogenetic, species delimitation, and time-calibrated analyses to test the hypothesis that $H$. copelandii is a species complex currently delimited by different Atlantic coastal systems. Results indicate that $H$. copelandii presents two well-delimited genetic lineages: one in the northern drainages of the Jucuruçu, Mucuri and Doce rivers, and the other in the southern region represented by the Paraíba do Sul River Basin. The time-calibrated phylogeny indicated a split between the two genetic lineages at around 2.8 million years ago (Ma), which might be related to headwater capture events during the Plio-Pleistocene. The discovery of a distinct genetic lineage for $H$. copelandii suggests distinct management plans for the northern and southern drainages. Such hidden diversity within the H. copelandii provides useful information for taxonomy and conservation across a severely impacted region of Brazil.
\end{abstract}

Keywords: biogeography; freshwater fish; hidden diversity; Neotropics; phylogeny; Pleistocene

\section{Introduction}

The Neotropical fish fauna is considered one of the most diversified globally, representing about $20 \%$ of the world's fish diversity [1,2]. Most of this diversity is associated with recent events of speciation that occurred during the Neogene and Quaternary due to palaeogeological changes of hydrographic basins [2-5], such as drainage reconfiguration [6,7] and sea-level fluctuations that promoted paleodrainage connections and reproductive isolation during the Pleistocene [8-10]. The conservation of mega-biodiversity obtained over hundreds of millions of years depends on accurate species identification, especially in ecosystems highly impacted by anthropogenic activities [11,12]. However, the assessment of such biological diversity is complex due to the high number of described and undescribed species $[13,14]$, the lack of phenotypic variation in cryptic species $[15,16]$, and the inadequate funding and training for taxonomic research [17,18].

Species identification of the Neotropical fish fauna has improved significantly with the establishment of molecular approaches $[19,20]$ and the combined analysis of morphological and molecular data [15,21-23]. Molecular-based methods, such as species delimitation using mitochondrial loci [24], have altered our perception of the fish diversity in the Neotropics $[20,25,26]$. These approaches have been helpful to resolve taxonomic uncertainties [27], detect hidden diversity [28-30], and contribute to an increase in the rate of discovery of new species, especially in cryptic lineages $[15,22,31-34]$. In this context, the 
application of molecular phylogenetic analyses provides insights about population histories, and relevant information for taxonomy and conservation of many species-rich groups of fishes.

Anostomidae is the second most species-rich family within the order Characiformes, only behind Characidae, with a total of 149 known species broadly distributed throughout South America [35-37]. Some anostomids have large body sizes and are commonly exploited in commercial and subsistence fisheries [36]. Despite their economic importance, the systematics and biogeography of complex anostomid genera represent significant challenges in Neotropical ichthyology. Although the phylogenetic relationships of anostomids have been explored recently [38-40], some genera and species groups still lack revision. As an example, species of the most species-rich genus Leporinus (>90 species [41]) present huge morphological variation in body shape, mouth position, number and shape of teeth, and color pattern, with the latter being traditionally used to infer putative subgroups based on the presence of vertical bars, lateral dark blotches, or longitudinal stripes [22,40,42-44].

Phylogenetic studies based on morphological and molecular approaches have characterized Leporinus as a paraphyletic genus [22,40], and recent integrative studies have reallocated some species into the newly described Megaleporinus [38] and Hypomasticus genera [45]. For example, the species popularly known as piava-vermelha (Figure 1), was previously allocated under the genus Leporinus, but it is now recognized as Hypomasticus copelandii $[45,46]$. This short-distance migratory species [47] is distributed across drainages from the Northeastern Atlantic Forest to the Paraíba do Sul ecoregions [48], such as Doce, Mucuri, Jucuruçu, and Paraíba do Sul river basins. These systems have been highly impacted by human activities, especially the Doce River which was severely affected by the Mariana's dam breach [12,49-51]. The relatively broad distribution along those rivers makes $H$. copelandii an interesting phylogeographic model to study speciation processes across Atlantic coastal rivers of South America.

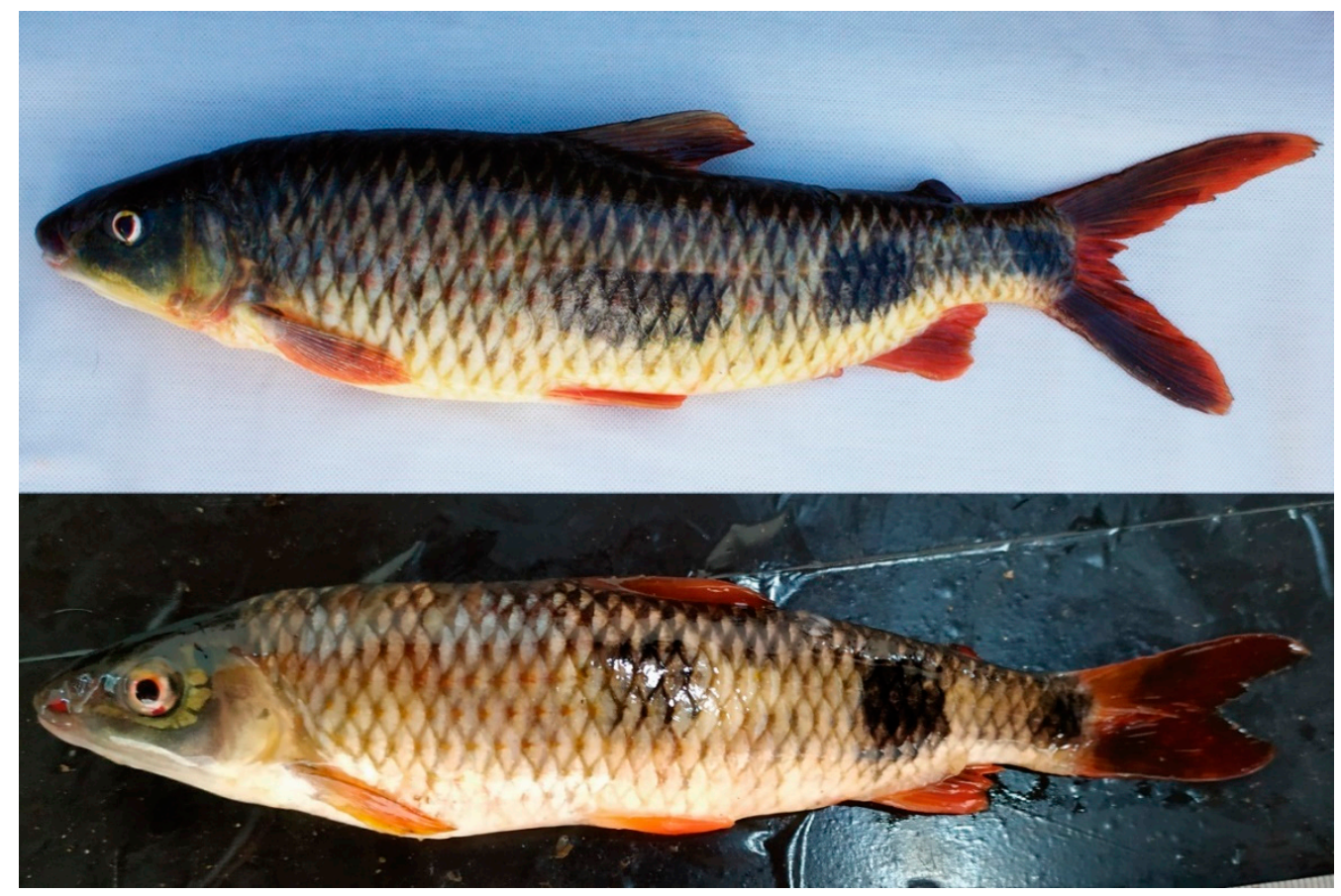

Figure 1. Representative specimens of Hypomasticus copelandii from the northern region in the Doce River (top), and the southern region in the Paraíba do Sul River (bottom). Photographs by T. Pessali (top) and A. Nobile (bottom).

Hypomasticus copelandii was described based on syntypes collected in the Paraíba do Sul, Doce, São Mateus, and Jequitinhonha basins [46] and may include at least three distinct species $[36,45,52]$. Morphological studies have suggested the possibility of the 
existence of distinct taxonomic units living in different coastal basins [43,45]. A recent conservation study generated genetic data for a few $H$. copelandii and detected intraspecific variation between samples from the Doce and Paraíba do Sul basins indicating a possible species complex [12]. However, this study used only four taxa and did not sample the entire distribution of the species. Clarification of species diversity within $H$. copelandii will provide useful information for taxonomy and conservation across a severely impacted region of Brazil.

We conducted a phylogeographic study of Hypomasticus copelandii using two mitochondrial and one nuclear locus and employed phylogenetic and species delimitation analyses to test the hypothesis that $H$. copelandii represents a species complex with multiple species along the coastal basins of the Northeastern Atlantic Forest and the Paraíba do Sul ecoregions. We also time-calibrated the phylogeny to infer putative evolutionary processes modulating lineage diversification along the coastal rivers of eastern Brazil.

\section{Materials and Methods}

\subsection{Taxon Sampling, DNA Extraction, and Sequencing}

Sample collections were conducted between June 2014 and August 2016 across drainages from the Northeastern Atlantic Forest and the Paraíba do Sul freshwater ecoregions [48] in the Brazilian states of Bahia, Minas Gerais, and São Paulo. Specimens of Hypomasticus copelandii were obtained from the Doce River Basin (DRB: $\mathrm{n}=13$ ), Mucuri River Basin (MRB: $\mathrm{n}=3$ ), Jucuruçu River Basin (JRB: $\mathrm{n}=4$ ), Paraíba do Sul River Basin (PSRB: $\mathrm{n}=6$ ), and from an aquaculture station of the Paraíba do Sul River Basin (Estação de Hidrobiologia e Aquicultura de Paraibuna-EHAP: $\mathrm{n}=7$ ) (Figure 2a). Fish specimens were collected according to Brazilian environmental laws through SISBIO/MMA permit No. 9793-1. Specimens were captured using gill nets and fins were clipped and stored on $96 \%$ ethanol at $4{ }^{\circ} \mathrm{C}$ in the Conservation Genetics Lab (LGC) at the Pontifical Catholic University of Minas Gerais (PUC Minas), Belo Horizonte, Brazil. Taxonomic identification was based on the literature [43] and vouchers were deposited at the fish collection of the Museum of Natural Sciences, PUC Minas, Belo Horizonte (MCNIP).

Extraction of genomic DNA was conducted using a modified salting-out protocol [53]. We sequenced fragments of the cytochrome c oxidase subunit I (COI), the 12S rRNA, and the first intron of the nuclear S7 ribosomal protein gene. Amplifications were performed using the universal primer cocktail for COI developed by [54], the primers for $12 S$ designed by [55], and the primers for S7 used by [56]. Polymerase chain reactions (PCR) for amplification of COI and S7 were performed with a total volume of $10 \mu \mathrm{L}$ including $1.0 \mu \mathrm{L}$ Phoneutria Buffer IB $10 \times, 0.3 \mu \mathrm{L}$ of dNTP $(10 \mathrm{mM})$ (Invitrogen, Waltham, MA, USA), $0.25 \mu \mathrm{L}$ of each primer $(10 \mu \mathrm{M}), 0.1 \mu \mathrm{L}$ of Taq DNA polymerase ( $5 \mathrm{U} / \mu \mathrm{L})$ (Invitrogen), $7.0 \mu \mathrm{L}$ of ultra-pure water, and $1.0 \mu \mathrm{L}$ of DNA template. For $12 S$, the PCRs were conducted with a total volume of $25 \mu \mathrm{L}$, containing $2.5 \mu \mathrm{L}$ of platinum buffer $10 \times, 0.5 \mu \mathrm{L}$ of $\mathrm{dNTP}$ $(10 \mathrm{mM})$ (Invitrogen, Waltham, MA, USA), $0.75 \mu \mathrm{L}$ of $\mathrm{MgCl} 2,0.25 \mu \mathrm{L}$ of each of the two primers $(10 \mu \mathrm{M}), 0.3 \mu \mathrm{L}$ of bovine serum albumin (BSA), $0.1 \mu \mathrm{L}$ of Taq DNA polymerase $(5 \mathrm{U} / \mu \mathrm{L})$ (Invitrogen, Waltham, MA, USA), $19.35 \mu \mathrm{L}$ of ultra-pure water, and $1.0 \mu \mathrm{L}$ of DNA template. Amplifications were performed using a thermocycler (Veriti 96-Well Thermal Cycler, Applied Biosystems, Beverly, MA, USA). For COI, amplifications consisted of an initial denaturation step of $2 \mathrm{~min}$ at $95^{\circ} \mathrm{C}$ followed by 35 cycles of denaturation with $30 \mathrm{~s}$ at $94{ }^{\circ} \mathrm{C}$; primer annealing with $54{ }^{\circ} \mathrm{C}$ for $30 \mathrm{~s}$, extension with $1 \mathrm{~min}$ at $72{ }^{\circ} \mathrm{C}$ followed by a final extension step of $10 \mathrm{~min}$ at $72{ }^{\circ} \mathrm{C}$. For $12 \mathrm{~S}$, amplification reactions were performed with an initial denaturation step of $10 \mathrm{~min}$ at $95^{\circ} \mathrm{C}$ followed by 35 cycles of denaturation for $30 \mathrm{~s}$ at $95^{\circ} \mathrm{C} ; 60{ }^{\circ} \mathrm{C}$ for $30 \mathrm{~s}$ for primer annealing, $1 \mathrm{~min}$ at $72{ }^{\circ} \mathrm{C}$ followed by a final extension of $7 \mathrm{~min}$ at $72^{\circ} \mathrm{C}$. For S7, amplifications were conducted with an initial denaturation step of $2 \mathrm{~min}$ at $94{ }^{\circ} \mathrm{C}$ followed by 35 cycles of denaturation for $45 \mathrm{~s}$ at $94{ }^{\circ} \mathrm{C} ; 59$ ${ }^{\circ} \mathrm{C}$ for $45 \mathrm{~s}$ for primer annealing, $45 \mathrm{~s}$ at $72{ }^{\circ} \mathrm{C}$ followed by a final extension of $7 \mathrm{~min}$ at 72 ${ }^{\circ} \mathrm{C}$. PCR products were visualized on $1 \%$ agarose gel, alongside negative controls and a size ladder, and positive amplifications were selected for DNA sequencing. Amplicons 
were sequenced bi-directionally using the BigDye Terminator v3.1 Cycle Sequencing Kit (Applied Biosystems, Inc., Beverly, MA, USA) following the manufacture's protocol and loaded onto the 3500 Genetic Analyzer (Applied Biosystems, Inc., Beverly, MA, USA).

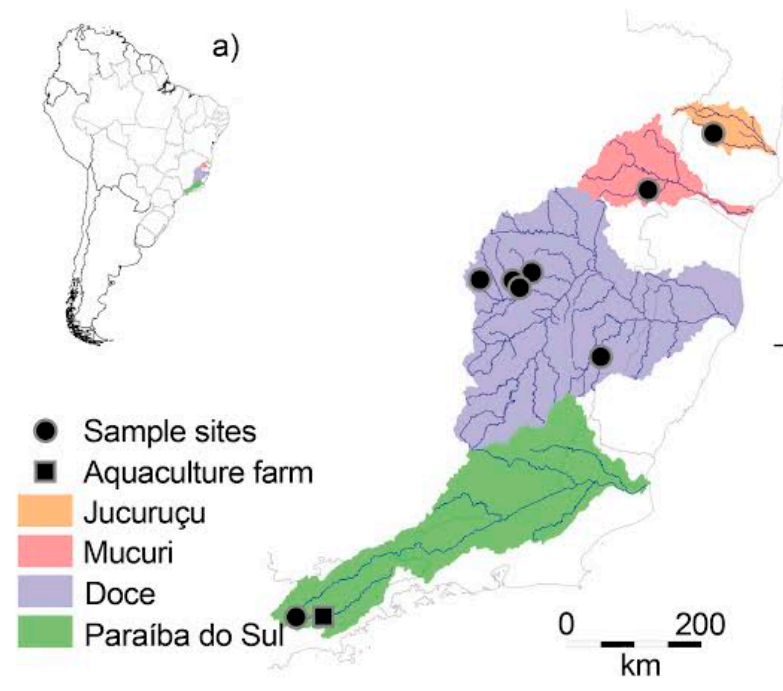

b)
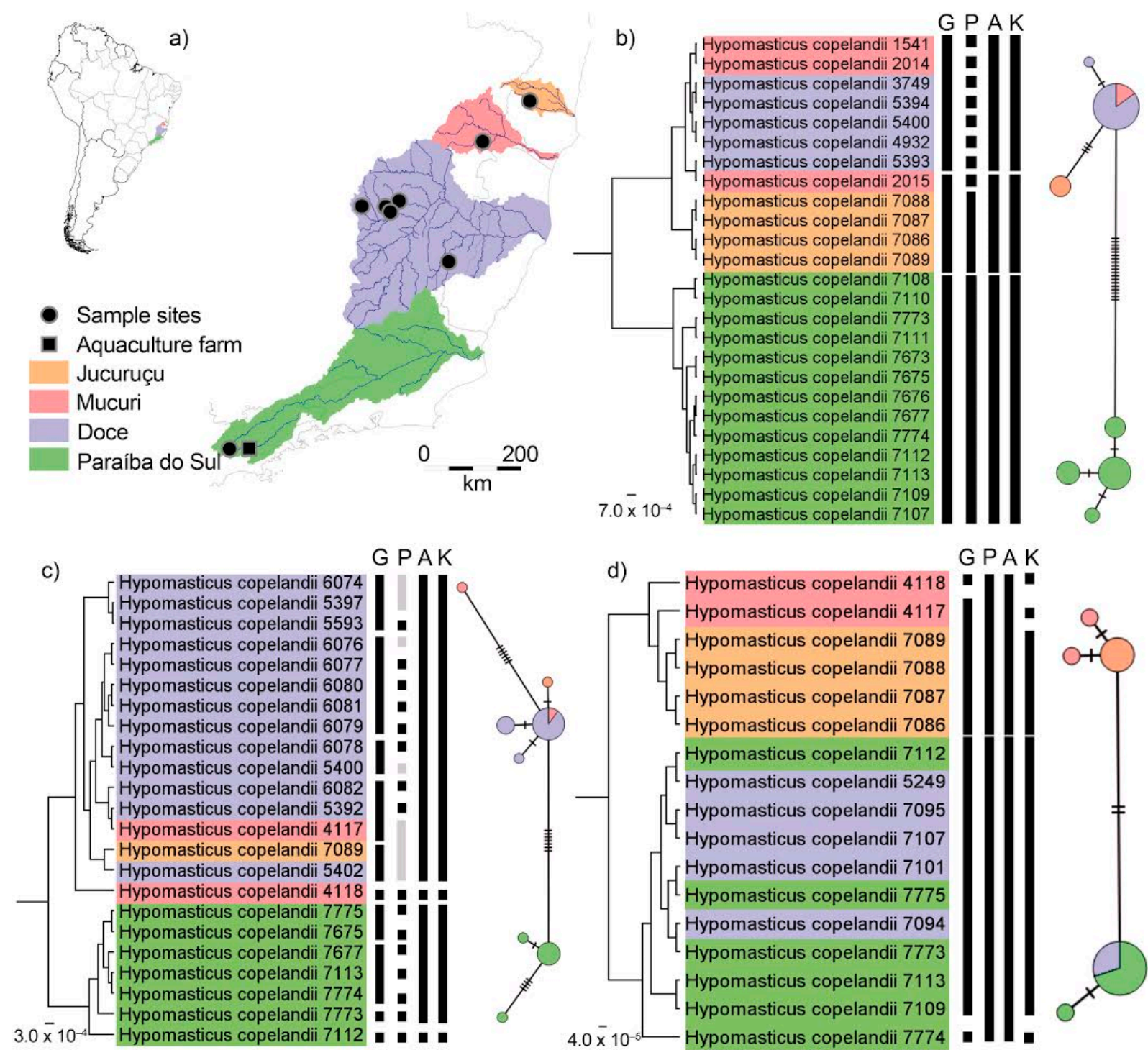

d)

$7.0 \overline{\times} 10^{-4}$ Hypomasticus copelandii 7109

GPAK

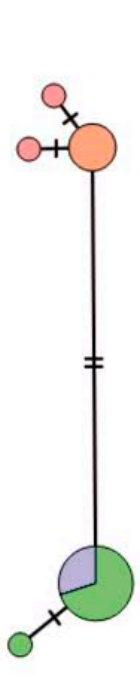

Figure 2. (a) Map showing sampled locations surveyed around the Northeastern Mata Atlântica and the Paraíba do Sul ecoregions and Bayesian phylogenetic ultrametric trees estimated from (b) COI, (c) 12S, and (d) S7 loci. Lineages are represented by different sizes and colors in accordance with each different species delimitation method ( $\mathrm{G}=\mathrm{GMYC}$; $\mathrm{P}=\mathrm{bPTP} ; \mathrm{A}=\mathrm{ABGD} ; \mathrm{K}=\mathrm{K} 2 \mathrm{P}$ genetic distances). Haplotype networks for each gene appears at right of each tree. Colors follow the map.

\subsection{Alignment and Phylogenetic Analyses}

DNA sequences were edited to generate a single consensus sequence for each individual using DNAbaser Sequence Assembler v4 software (Heracle BioSoft; www.dnabaser.com, accessed on 24 June 2020). The newly-generated contigs were deposited in GenBank under the accession codes MK770202-MK770236 (COI), MH187578-MH187599 (12S) and MF850381-MF850398 (S7). Vouchers, locality information and GenBank codes are summarized in Table 1. We also included 12 additional COI sequences $(\mathrm{DRB}=9, \mathrm{MRB}=3$ ) available from Barcode of Life Database system (BOLD; www.boldsystems.org, accessed on 24 June 2020) [57]. As outgroups, we used three sequences of Hypomasticus thayeri 
(MF850389.1), Hypomasticus mormyrops (MT427917.1) and Hypomasticus steindachneri (LGC 2984) available in GenBank or sequenced in our lab.

Table 1. Voucher specimens and locality information of taxa used in this study.

\begin{tabular}{|c|c|c|c|c|c|}
\hline Taxon & Voucher & Tissues & Locality & Coordinates & $\begin{array}{l}\text { Accession Numbers } \\
\quad(\text { COI, 12S, S7) }\end{array}$ \\
\hline Hypomasticus mormyrops & 29,070 & LBP29070 & PSRB & $23 \mathrm{~S} 22^{\prime} 26^{\prime \prime} 46 \mathrm{~W} 03^{\prime} 11^{\prime \prime}$ & GU702177.1, -, - \\
\hline Hypomasticus steindachneri & - & LGC2984 & Jequitinhonha RB & $16 \mathrm{~S} 59^{\prime} 68^{\prime \prime} 41 \mathrm{~W} 59^{\prime} 82^{\prime \prime}$ & - \\
\hline Hypomasticus copelandii & - & LGC3749 & DRB & $18 \mathrm{~S} 58^{\prime} 48^{\prime \prime} 43 \mathrm{~W} 26^{\prime} 11^{\prime \prime}$ & MK770203, -, - \\
\hline Hypomasticus copelandii & MCNIP-1398 & LGC4116 & MRB & $17 \mathrm{~S} 35^{\prime} 824^{\prime \prime} 40 \mathrm{~W} 59^{\prime} 205^{\prime \prime}$ & MUCU153-14, -, - \\
\hline Hypomasticus copelandii & MCNIP-1398 & LGC4117 & MRB & $17 \mathrm{~S} 35^{\prime} 824^{\prime \prime} 40 \mathrm{~W} 59^{\prime} 205^{\prime \prime}$ & $\begin{array}{c}\text { MUCU154-14, } \\
\text { MH187580, MF850394 }\end{array}$ \\
\hline Hypomasticus copelandii & MCNIP- 1398 & LGC4118 & MRB & $17 \mathrm{~S} 35^{\prime} 824^{\prime \prime} 40 \mathrm{~W} 59^{\prime} 205^{\prime \prime}$ & $\begin{array}{c}\text { MUCU120-14, } \\
\text { MH187587, F850395 }\end{array}$ \\
\hline Hypomasticus copelandii & - & LGC5249 & DRB & $42 \mathrm{~W} 42^{\prime} 26^{\prime \prime} 18 \mathrm{~S} 53^{\prime} 52^{\prime \prime}$ &,,-- MF850383 \\
\hline Hypomasticus copelandii & - & LGC5392 & DRB & $42 \mathrm{~W} 40^{\prime} 59^{\prime \prime} 18 \mathrm{~S} 53^{\prime} 50^{\prime \prime}$ & -, MH187599, - \\
\hline Hypomasticus copelandii & - & LGC5393 & DRB & $18 \mathrm{~S} 53^{\prime} 30^{\prime \prime} 42 \mathrm{~W} 41^{\prime} 44^{\prime \prime}$ & MK770205, -, - \\
\hline Hypomasticus copelandii & - & LGC5394 & DRB & $18 \mathrm{~S} 53^{\prime} 30^{\prime \prime} 42 \mathrm{~W} 41^{\prime} 44^{\prime \prime}$ & MK770206 -, - \\
\hline Hypomasticus copelandii & - & LGC5397 & DRB & $42 \mathrm{~W} 56^{\prime} 31^{\prime \prime} 19 \mathrm{~S} 00^{\prime} 23^{\prime \prime}$ & -, MH187598, - \\
\hline Hypomasticus copelandii & - & LGC5400 & DRB & $18 \mathrm{~S} 59^{\prime} 18^{\prime \prime} 42 \mathrm{~W} 57^{\prime} 49^{\prime \prime}$ & MK770207, MH187579, - \\
\hline Hypomasticus copelandii & - & LGC5402 & DRB & $42 \mathrm{~W} 57^{\prime} 24^{\prime \prime} 18 \mathrm{~S} 59^{\prime} 43^{\prime \prime}$ & -, MH187597, - \\
\hline Hypomasticus copelandii & - & LGC5593 & DRB & $19 \mathrm{~S} 59^{\prime} 03^{\prime \prime} 41 \mathrm{~W} 43^{\prime} 03^{\prime \prime}$ & MK770209, MH187586, - \\
\hline Hypomasticus thayeri & - & LGC5784 & DRB & $18 \mathrm{~S} 55^{\prime} 01^{\prime \prime} 43 \mathrm{~W} 27^{\prime} 42^{\prime \prime}$ & MF850389 \\
\hline Hypomasticus copelandii & - & LGC6074 & DRB & $42 \mathrm{~W} 52^{\prime} 57^{\prime \prime} 19 S 03^{\prime} 41^{\prime \prime}$ & -, MH187596, - \\
\hline Hypomasticus copelandii & - & LGC6076 & DRB & $42 \mathrm{~W} 52^{\prime} 34^{\prime \prime} 19 \mathrm{~S} 04^{\prime} 37^{\prime \prime}$ & -, MH187595, - \\
\hline Hypomasticus copelandii & - & LGC6077 & DRB & $42 \mathrm{~W} 52^{\prime} 34^{\prime \prime} 19 \mathrm{~S} 04^{\prime} 37^{\prime \prime}$ & -, MH187594, - \\
\hline Hypomasticus copelandii & - & LGC6078 & DRB & $42 \mathrm{~W} 57^{\prime} 49^{\prime \prime} 18 \mathrm{~S} 59^{\prime} 18^{\prime \prime}$ & -, MH187593, - \\
\hline Hypomasticus copelandii & - & LGC6079 & DRB & $42 \mathrm{~W} 57^{\prime} 39^{\prime \prime} 18 \mathrm{~S} 59^{\prime} 38^{\prime \prime}$ & -, MH187592, - \\
\hline Hypomasticus copelandii & - & LGC6080 & DRB & $42 \mathrm{~W} 56^{\prime} 31^{\prime \prime} 19 \mathrm{~S} 00^{\prime} 23^{\prime \prime}$ & -, MH187591, - \\
\hline Hypomasticus copelandii & - & LGC6081 & DRB & $42 \mathrm{~W} 55^{\prime} 28^{\prime \prime} 19 \mathrm{~S} 03^{\prime} 04^{\prime \prime}$ & -, MH187590, - \\
\hline Hypomasticus copelandii & - & LGC6082 & DRB & $42 \mathrm{~W} 41^{\prime} 44^{\prime \prime} 18 \mathrm{~S} 53^{\prime} 30^{\prime \prime}$ & -, MH187589, - \\
\hline Hypomasticus copelandii & - & LGC7086 & JRB & $44 \mathrm{~W} 59^{\prime} 55^{\prime \prime} 79 \mathrm{~S} 51^{\prime} 27^{\prime \prime}$ & MK770212, -, MF850392 \\
\hline Hypomasticus copelandii & - & LGC7087 & JRB & $44 \mathrm{~W} 59^{\prime} 55^{\prime \prime} 79 \mathrm{~S} 51^{\prime} 27^{\prime \prime}$ & MK770213, -, MF850393 \\
\hline Hypomasticus copelandii & - & LGC7088 & JRB & $44 \mathrm{~W} 59^{\prime} 55^{\prime \prime} 79 \mathrm{~S} 51^{\prime} 27^{\prime \prime}$ & MK770214, -, MF850390 \\
\hline Hypomasticus copelandii & - & LGC7089 & JRB & $44 \mathrm{~W} 59^{\prime} 55^{\prime \prime} 79 \mathrm{~S} 51^{\prime} 27^{\prime \prime}$ & $\begin{array}{c}\text { MK770215, MH187585, } \\
\text { MF850391 }\end{array}$ \\
\hline Hypomasticus copelandii & - & LGC7094 & DRB & $19 S 44^{\prime} 58^{\prime \prime} 41 \mathrm{~W} 46^{\prime} 58^{\prime \prime}$ &,,-- MF850384 \\
\hline Hypomasticus copelandii & - & LGC7095 & DRB & $19 \mathrm{~S} 44^{\prime} 58^{\prime \prime} 41 \mathrm{~W} 46^{\prime} 58^{\prime \prime}$ &,,-- MF850385 \\
\hline Hypomasticus copelandii & - & LGC7101 & DRB & $19 S 44^{\prime} 58^{\prime \prime} 41 \mathrm{~W} 46^{\prime} 58^{\prime \prime}$ &,,-- MF850381 \\
\hline Hypomasticus copelandii & - & LGC7107 & PSRB & $23 \mathrm{~S} 22^{\prime} 25^{\prime \prime} 45 \mathrm{~W} 39^{\prime} 59^{\prime \prime}$ & MK770216, -, MF850386 \\
\hline Hypomasticus copelandii & - & LGC7108 & PSRB & $23 \mathrm{~S} 22^{\prime} 25^{\prime \prime} 45 \mathrm{~W} 39^{\prime} 59^{\prime \prime}$ & MK770217, -, - \\
\hline Hypomasticus copelandii & - & LGC7109 & PSRB & $23 \mathrm{~S} 22^{\prime} 25^{\prime \prime} 45 \mathrm{~W} 39^{\prime} 59^{\prime \prime}$ & MK770218, -, MF850387 \\
\hline Hypomasticus copelandii & - & LGC7110 & PSRB & $23 S 22^{\prime} 25^{\prime \prime} 45 \mathrm{~W} 39^{\prime} 59^{\prime \prime}$ & MK770219,-,- \\
\hline
\end{tabular}


Table 1. Cont.

\begin{tabular}{|c|c|c|c|c|c|}
\hline Taxon & Voucher & Tissues & Locality & Coordinates & $\begin{array}{l}\text { Accession Numbers } \\
\quad(C O I, 12 S, \text { S7) }\end{array}$ \\
\hline Hypomasticus copelandii & - & LGC7111 & PSRB & $23 S 22^{\prime} 25^{\prime \prime} 45 \mathrm{~W} 39^{\prime} 59^{\prime \prime}$ & MK770220, -, - \\
\hline Hypomasticus copelandii & - & LGC7112 & PSRB & $23 S 22^{\prime} 25^{\prime \prime} 45 \mathrm{~W} 39^{\prime} 59^{\prime \prime}$ & $\begin{array}{c}\text { MK770221, MH187578, } \\
\text { MF850388 }\end{array}$ \\
\hline Hypomasticus copelandii & - & LGC7113 & PSRB & 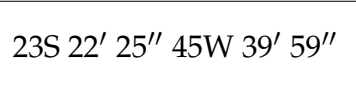 & $\begin{array}{c}\text { MK770222, MH187584, } \\
\text { MF850382 }\end{array}$ \\
\hline Hypomasticus copelandii & - & LGC7673 & PSRB & $23 S 22^{\prime} 25^{\prime \prime} 45 \mathrm{~W} 39^{\prime} 59^{\prime \prime}$ & MK770231, -, - \\
\hline Hypomasticus copelandii & - & LGC7675 & PSRB & $23 \mathrm{~S} 22^{\prime} 25^{\prime \prime} 45 \mathrm{~W} 39^{\prime} 59^{\prime \prime}$ & MK770232, MH187583, - \\
\hline Hypomasticus copelandii & - & LGC7676 & PSRB & $45 \mathrm{E} 49^{\prime} 01^{\prime \prime} 36 \mathrm{~S} 16^{\prime} 35^{\prime \prime}$ & MK770233, -, - \\
\hline Hypomasticus copelandii & - & LGC7677 & PSRB & $45 \mathrm{E} 49^{\prime} 01^{\prime \prime} 36 \mathrm{~S} 16^{\prime} 35^{\prime \prime}$ & MK770234, MH187582, - \\
\hline Hypomasticus copelandii & - & LGC7773 & PSRB & $23 S 22^{\prime} 25^{\prime \prime} 45 \mathrm{~W} 39^{\prime} 59^{\prime \prime}$ & MK770235, -, - \\
\hline Hypomasticus copelandii & - & LGC7774 & PSRB & $23 S 22^{\prime} 25^{\prime \prime} 45 W 39^{\prime} 59^{\prime \prime}$ & MK770236, -, - \\
\hline Hypomasticus copelandii & - & LGC7775 & DRB & $23 S 22^{\prime} 25^{\prime \prime} 45 \mathrm{~W} 39^{\prime} 59^{\prime \prime}$ & $\begin{array}{l}- \text {, undeposited, } \\
\text { undeposited }\end{array}$ \\
\hline
\end{tabular}

Sequences of COI and S7 comprising the final matrix were aligned using the ClustalW tool [58] implemented in MEGA v7.0 [59] under default parameters. Sequences of $12 S$ were aligned using the MAFFT software (https://mafft.cbrc.jp/alignment/server/, accessed on 24 June 2020, Kazutaka Katoh, Osaka, Japan), using the "Q-INS-i" option. To evaluate the occurrence of substitution saturation, we estimated the index of substitution saturation in asymmetrical (Iss.cAsym, Xuhua Xia, Ottawa, Canada) and symmetrical (Iss.cSym, Xuhua Xia, Ottawa, Canada) topologies using DAMBE v5.3.38 [60], and estimated genetic distances using MEGA v7.0. All sequences were binned into species groups and the overall mean distance (distance among all specimens), the intragroup distances (among specimens within each species group), and intergroup distances (among species groups) were calculated using the best-fitting model of nucleotide evolution determined by the Akaike Information Criterion (AIC) using jModelTest v2.1.6 [61,62] available on CIPRES Science Gateway v3.1 [63]. The neighbor-joining (NJ) trees with 1000 bootstrap pseudoreplicates were generated using MEGA v7.0, and the maximum likelihood (ML) tree under the GTRGAMMA model with 1000 bootstrap pseudoreplicates were estimated in RAxML HPC v8 on XSEDE [64] implemented on CIPRES.

\subsection{Species Delimitation Analyses}

To test the hypothesis that allopatric populations may represent different species for each river basin, four species delimitation methods were performed for each of the three molecular markers: genetic distances, general mixed Yule coalescent model (GMYC) [65], bPTP [66], and ABGD [67]. (1) The genetic distance analyses based on the best-fitting model of nucleotide evolution were obtained with threshold values of $2 \%$ for COI [68], $0.4 \%$ for $12 \mathrm{~S}$ [69] and $0.1 \%$ for S7, defined by threshVal function from the threshold optimization analysis in SPIDER package [70] implemented in R [71], as there are no previous references delimiting cut-off values for the S7 marker. The distance analyses allow us to understand the levels of genetic diversity by calculating the relative number of substitutions among taxa. (2) The GMYC model was applied using an ultrametric tree generated in BEAST v1.8.4 [72]. The relaxed lognormal distribution and the birth-death process as tree priors were used as clock models. The GTR + G + I was used as the model of nucleotide evolution and the Markov chain (MCMC) procedure was used with 100 million generations with a sampling frequency of 10,000 generations. Convergence was indicated by Tracer v1.7 [73] with estimated sample size (ESS) values above 200. An appropriate number of trees (first $10 \%$ ) from each run was discarded as burn-in and the maximum clade credibility (MCC) 
topology was obtained in TreeAnnotator v1.4.7 [74] and visualized in FigTree v1.4.3. The annotated tree was included in the GMYC analysis in R with the "splits" package (Species Limits by Threshold Statistics; http:/ / r-forge.r-project.org/projects/splits, accessed on 24 June 2020) and a single threshold strategy using default scaling parameters. (3) The bPTP analysis does not require an ultrametric gene tree and instead uses a Newick tree as input file with branch lengths representing the number of nucleotide substitutions. We used the neighbor-joining tree generated in MEGA7 as input file. (4) The ABGD automatically defines sequences into hypothetical candidate species based on confidence limits for intraspecific divergence. ABGD first uses a range of prior intraspecific divergences to divide the data into groups based on a statistically inferred barcode gap, and then recursively applies the same procedure to the groups obtained in the first step. ABGD analyses were performed using the web interface (http:/ / wwwabi.snv.jussieu.fr/public/ $\mathrm{abgd} /$, accessed on 24 June 2020) with a relative gap width value of $X=1.5$, while other parameters were set as default. Assignments for intraspecific divergence (P-distances) between 0.001 and 0.100 were recorded.

\subsection{Divergence Time Estimates}

Divergence time estimates were accessed using the newest multilocus dataset of Anostomidae that includes 66 taxa, six genes (16S, COI, Cytb, Rag1, Rag2, and Myh6), and $5321 \mathrm{bp}$ [39]. We reduced this matrix by removing 15 anostomids because they had only morphological data and 10 outgroups to minimize uncertainties in tree reconstruction and because our focus was the estimation of node ages for Hypomasticus copelandii. We then added six COI sequences of $H$. copelandii generated here to have a matrix with 47 taxa and 5,321 bp; Chilodus punctatus (Chilodontidae) was the root of the phylogeny. Although the six specimens lack the other five genes, there is one taxon of Hypomasticus copelandii (MCNIP 459) in the matrix with available sequences for all genes except 16S rRNA [22,39]. This 47-taxa matrix was used as input file for the time-calibrated analyses.

We estimated the best-fitting model of nucleotide substitution available for BEAST using the Bayesian information criterion in PartitionFinder v1.1.4 [75] by partitioning the $16 \mathrm{~S}$ as a single scheme and subdividing the other loci by codon position. The partitioned matrix (nexus) was used as input file for BEAST v2 [74,76]. We used an uncorrelated lognormal distribution under a relaxed clock and the three priors: two fossils and one root constraint. The first fossil is tLeporinus scalabrinii [77] (holotype: MACN A-9880), first described as + Arrhinolemur scalabrinii, based on a single small and incomplete skull collected in the Ituzaingó Formation (9-6 million years ago, Ma), Paraná, Entre Ríos Province, Argentina [78]. The authors reevaluated the phylogenetic position of $+L$. scalabrinii using the morphological matrix of Anostomidae [40] and found a close relationship with Abramites hypselonotus [79], with that pair of taxa being sister to L. striatus [80]. Later on, the presence of morphological similarities between L. scalabrinii and Megaleporinus were brought to light [30]. Our molecular reconstructions and previous ones $[30,39]$ have found Megaleporinus as sister to Abramites and this pair sister to L. striatus. Thus, we placed the fossil at the base of the entire clade uniting L. striatus, A. hypselonotus, and five species of Megaleporinus (lognormal distribution; offset $=6.0$; mean $=5.0$; stdev $=1.0$ ). The second prior follows the calibration of Sidlauskas et al. [39] and involves the anostomid teeth from Cenozoic deposits of the Contamana region in the Peruvian Amazon (41-26.6 Ma). The fossil teeth likely represent an ancestral dentition of modern Hypomasticus, Leporellus, Leporinus, and Megaleporinus and, due to the uncertainty of its phylogenetic placement, we included it as the crown age of the entire family Anostomidae (lognormal distribution; offset $=26.6$; mean $=5.0$; stdev $=1.0$ ) [39]. Finally, we used a root constraint representing the split of Anostomidae and Chilodontidae based on a recent time reconstruction of the order Characiformes [5] dated to the Paleocene and early Eocene at around 66-48 Ma (normal distribution; mean $=62.5$; sigma $=7.0$ ). We used the birth-death process for the speciation likelihood and a random starting tree. The analysis ran 10 million generations sampling trees at every 1000th generation. Convergence was evaluated in Tracer v. 1.7 
using effective sample size (ESS), prior convergence, and likelihood (lnL) of the priors and posterior estimates after a $10 \%$ burn-in removal. Stationarity and sufficient mixing of parameters (ESS > 200) were checked using Tracer v1.7. The maximum clade credibility tree was obtained from the 9001 saved trees in TreeAnnotator v2. A final tree was obtained using FigTree v1.4.2.

\section{Results}

\subsection{Genetic Distances}

We obtained 34 sequences of COI for Hypomasticus copelandii (DRB $=9, \mathrm{JRB}=4$, $\mathrm{PSRB}=6, \mathrm{EHAP}=15), 23$ sequences of $12 \mathrm{~S}$ rRNA $(\mathrm{DRB}=13, \mathrm{MRB}=2, \mathrm{JRB}=1, \mathrm{PSRB}=5$, $\mathrm{EHAP}=2)$, and 17 sequences of the nuclear $\mathrm{S} 7$ gene $(\mathrm{DRB}=5, \mathrm{MRB}=2, \mathrm{JRB}=4, \mathrm{PSRB}=3$, EHAP $=3)$. The final COI matrix consisted of 630 bp with 26 variable sites $(\sim 4.1 \%)$, the $12 S$ rRNA dataset consisted of 466 bp with 21 variable sites (4.5\%), and the matrix of the nuclear S7 consisted of $625 \mathrm{bp}$ with five variable sites $(0.8 \%)$. The best models of nucleotide evolution were K2P (COI), HKY (12S), and TrN (S7). Overall mean of genetic distances was $0.020 \pm 0.004(\mathrm{COI}), 0.010 \pm 0.003(12 S)$, and $0.002 \pm 0.001$ (S7). Values for intra and intergroup genetic distances are presented for each gene in Tables $2-4$. Importantly, results show a clear division in two genetic units: the herein named "northern group" encompassing specimens from Doce, Mucuri, and Jucuruçu rivers, and the "southern group" comprising specimens from the Paraíba do Sul Basin. This is evidenced by relatively low genetic distances between samples inside the northern (0.000-0.009) and the southern (0.001-0.005) groups (Tables 2-4). Relatively high intergroup genetic distances were observed between samples of the two lineages using the mitochondrial loci (0.017-0.042) while the nuclear S7 resulted in slightly lower values (0.000-0.006) (Tables 2-4).

Table 2. Pairwise K2P genetic distance among genetic lineages of Hypomasticus (below diagonal) and values of standard error (above diagonal) using the COI gene dataset. Numbers in bold represent intragroup K2P genetic distance. DRB = Doce River Basin; EHAP = Estação de Hidrobiologia e Aquicultura de Paraibuna; JRB = Jucuruçu River Basin; MRB = Mucuri River Basin; PRSB = Paraíba do Sul River Basin.

\begin{tabular}{llccccc}
\hline & Lineages & $\mathbf{1}$ & $\mathbf{2}$ & $\mathbf{3}$ & $\mathbf{4}$ & $\mathbf{5}$ \\
\hline 1 & Hypomasticus copelandii DRB & $\mathbf{0 . 0 0 0}$ & 0.000 & 0.003 & 0.008 & 0.008 \\
2 & Hypomasticus copelandii MRB & 0.000 & $\mathbf{0 . 0 0 0}$ & 0.003 & 0.008 & 0.008 \\
3 & Hypomasticus copelandii JRB & 0.005 & 0.005 & $\mathbf{0 . 0 0 0}$ & 0.008 & 0.008 \\
4 & Hypomasticus copelandii PSRB & 0.036 & 0.036 & 0.042 & $\mathbf{0 . 0 0 2}$ & 0.001 \\
5 & Hypomasticus copelandii EHAP & 0.035 & 0.035 & 0.041 & 0.002 & $\mathbf{0 . 0 0 1}$ \\
\hline
\end{tabular}

Table 3. Pairwise K2P genetic distance among genetic lineages of Hypomasticus (below diagonal) and values of standard error (above diagonal), using the rRNA 12S dataset. Numbers in bold represent intragroup K2P genetic distance. DRB = Doce River Basin; EHAP = Estação de Hidrobiologia e Aquicultura de Paraibuna; JRB = Jucuruçu River Basin; MRB = Mucuri River Basin; PRSB = Paraíba do Sul River Basin.

\begin{tabular}{llccccc}
\hline & \multicolumn{1}{c}{ Lineages } & $\mathbf{1}$ & $\mathbf{2}$ & $\mathbf{3}$ & $\mathbf{4}$ & $\mathbf{5}$ \\
\hline 1 & Hypomasticus copelandii DRB & $\mathbf{0 . 0 0 1}$ & 0.003 & 0.002 & 0.006 & 0.006 \\
2 & Hypomasticus copelandii MRB & 0.007 & $\mathbf{0 . 0 1 3}$ & 0.004 & 0.007 & 0.007 \\
3 & Hypomasticus copelandii JRB & 0.003 & 0.009 & - & 0.006 & 0.006 \\
4 & Hypomasticus copelandii PSRB & 0.017 & 0.023 & 0.018 & $\mathbf{0 . 0 0 1}$ & 0.002 \\
5 & Hypomasticus copelandii EHAP & 0.021 & 0.027 & 0.023 & 0.005 & $\mathbf{0 . 0 0 1}$ \\
\hline
\end{tabular}


Table 4. Pairwise K2P genetic distance among genetic lineages of Hypomasticus (below diagonal) and values of standard error (above diagonal) using the S7 dataset. Numbers in bold represent intragroup K2P genetic distance. DRB = Doce River Basin; EHAP = Estação de Hidrobiologia e Aquicultura de Paraibuna; JRB = Jucuruçu River Basin; MRB = Mucuri River Basin; PRSB = Paraíba do Sul River Basin.

\begin{tabular}{llccccc}
\hline & Lineages & $\mathbf{1}$ & $\mathbf{2}$ & $\mathbf{3}$ & $\mathbf{4}$ & $\mathbf{5}$ \\
\hline 1 & Hypomasticus copelandii DRB & $\mathbf{0 . 0 0 0}$ & 0.003 & 0.002 & 0.001 & 0.000 \\
2 & Hypomasticus copelandii MRB & 0.005 & $\mathbf{0 . 0 0 3}$ & 0.001 & 0.003 & 0.003 \\
3 & Hypomasticus copelandii JRB & 0.003 & 0.002 & $\mathbf{0 . 0 0 0}$ & 0.002 & 0.002 \\
4 & Hypomasticus copelandii PSRB & 0.001 & 0.006 & 0.004 & $\mathbf{0 . 0 0 2}$ & 0.001 \\
5 & Hypomasticus copelandii EHAP & 0.000 & 0.005 & 0.003 & 0.001 & $\mathbf{0 . 0 0 1}$ \\
\hline
\end{tabular}

In the COI dataset, the intragroup distances ranged from 0.000 within Doce (DRB), Mucuri (MRB), and Jucuruçu (JRB) to 0.002 within Paraíba do Sul (PSRB) (Table 2). Pairwise intergroup distances ranged from $0.000 \pm 0.000$ (DRB vs. MRB) to $0.042 \pm 0.020$ (PSRB vs. JRB). Relatively low genetic distances indicating higher similarity were found between DRB, MRB, and JRB lineages (northern group), and between PSRB and the aquaculture farm at Paraíba do Sul (EHAP) lineages (southern group). Higher distances were observed between PSRB or EHAP compared to each of the other lineages (Table 2, Figure S1). In the $12 \mathrm{~S}$ dataset, the intragroup genetic distances ranged from 0.001 within DRB, PSRB, EHAP, and JRB to 0.013 within MRB (Table 3). Pairwise intergroup distances between H. copelandii lineages ranged from $0.003 \pm 0.002$ between DRB and JRB to $0.027 \pm 0.007$ between MRB and EHAP (Table 3, Figure S2). Finally, in the S7 dataset, intragroup genetic distances ranged from 0.000 within DRB and JRB to 0.003 within H. copelandii MRB (Table 4). Pairwise intergroup distances between lineages ranged from $0.000 \pm 0.000$ (DRB vs. PSRB) to $0.006 \pm 0.003$ (PSRB vs. MRB) (Table 4, Figure S3).

\subsection{Species Delimitation}

Species delimitation analyses using $\mathrm{COI}$ and $12 \mathrm{~S}$ datasets separated samples in the same two clusters: (1) the southern group: Paraíba do Sul lineage (PRSB + EHAP; $\mathrm{ML}=100 \%$ bootstrap), and (2) the northern group: Doce, Mucuri, and Jucuruçu rivers (DRB + MRB + JRB; ML $=99 \%$ and 100\% bootstrap, respectively) (Figures S4 and S5). Both $\mathrm{COI}$ and $12 \mathrm{~S}$ datasets resulted in the monophyly of the northern group (DRB + MRB + JRB), and the southern group (Figure $2 b, c)$. Contrastingly, the nuclear S7 merged individuals from the Doce with Paraiba do Sul samples ( $M L=100 \%$ bootstrap), segregating them in a different cluster from the MRB $+\mathrm{JRB}$ ( $\mathrm{ML}=100 \%$ bootstrap) (Figures $2 \mathrm{~d}$ and S6). Differences among methods involved the over-splitting of the bPTP in the COI and $12 \mathrm{~S}$ datasets (Figure $2 b, c$ ), the delimitation of a distinct lineage for the sample \#4118 from the Mucuri Basin in the 12S (Figure 2c), and the delimitation of a single lineage including samples of Doce and Paraíba do Sul in the S7 dataset (Figure 2d). Haplotype network analyses indicated a clear northern/southern distinction with a relatively high number of polymorphisms in the mitochondrial datasets (Figure 2).

With COI, the GMYC results suggested three lineages with the additional JRB (confidence interval 2-9 species, the maximum likelihood of null model $=212.1482$; the maximum likelihood of GMYC model $=214.7$; threshold time $=-0.0017$ ). The maximum likelihood solution of COI-bPTP delimited 10 lineages and suggested a clear separation between the hypothesized subgroups of $H$. copelandii (Figure $2 \mathrm{~b}$ ). The COIABGD resulted in seven partitions in which partition one (prior maximal distance $p=0.001$ ) indicated three species and the JRB lineage as a different species relative to the $\mathrm{DRB}+\mathrm{MRB}$ lineage. 
Using 12S, the GMYC analysis suggested ten species (confidence interval 1-22 species, maximum likelihood of null model $=197.2652$; maximum likelihood of GMYC model $=197.5237$; threshold time $=-0.0003$ ). The ML solution of 12S-bPTP delimited a high number of 20 MOTUs and suggested a clear separation between the subgroups $\mathrm{DRB}+\mathrm{MRB}+\mathrm{JRB}$ and PSRB + EHAP (Figure 2c). The 12S-ABGD analysis resulted in seven partitions ranging from 3 to 13 groups, with partition one (prior maximal distance $p=0.001$ ) indicating four species. Furthermore, 12s-ABGD results considered the subgroup $\mathrm{DRB}+\mathrm{MRB}+\mathrm{JRB}$ as a different species from PSRB + EHAP. All methods separated the individual \#4118 from DRB as a distinct lineage.

The nuclear marker S7 presented different results (Figure 2d). The S7-GMYC analysis recovered four lineages (confidence interval 1-7 species, maximum likelihood of null model = 163.5317; maximum likelihood of GMYC model $=164.0285$; threshold time $=-0.0001$ ). The 12S-bPTP approach resulted in two MOTUs, with a split between H. copelandii subgroups: DRB + PSRB and MRB + JRB. The 12S-ABGD resulted in nine partitions ranging from two to nine groups, with the partition one (prior maximal distance $p=0.001$ ) indicating nine species. These results considered the $H$. copelandii JRB as a different species from $H$. copelandii $\mathrm{DRB}+\mathrm{PSRB}+\mathrm{EHAP}$ and H. copelandii MRB. Moreover, this analysis indicated two species within the subgroup PSRB + MRB (Figure 2d).

\subsection{Timing of Diversification of Hypomasticus Copelandii}

The concatenated matrix, including six genes, contained $5321 \mathrm{bp}$ spanning 47 taxa (14 genera, 40 species of the Anostomidae and the root Chilodus punctatus). PartitionFinder resulted in 15 schemes and six different model combinations (Supplementary Materials). All data were further tested to investigate the occurrence of substitution saturation, and the results did not show any significant saturation (Iss < Iss.C; Supplementary Materials). The time-calibrated phylogeny estimated an Early Miocene stem age for Hypomasticus and the split of the genus with a major clade (Abramites, Anostomoides, Hypomasticus pachycheilus, Laemolyta, Leporinus, Megaleporinus, Rhytiodus, and Schizodon) at around $22.8 \mathrm{Ma}$ (28.8-16.9 Ma, 95\% highest posterior density, HPD) (Figure 3). The first two internal ramifications occurred in the Miocene with $\mathrm{H}$. megalepis splitting from the clade composed by H. steindachneri, H. mormyrops and H. copelandii at approximately $19.1 \mathrm{Ma}(25.3-13.6 \mathrm{Ma}$, $95 \%$ HPD). Then, H. steindachneri split from the H. mormyrops $+H$. copelandii clade during the Late Miocene at around 6.1 Ma (8.5-3.8 Ma, 95\% HPD). The diversification of the two subclades of $H$. copelandii occurred during the Late Pliocene-Early Pleistocene at approximately 2.8 Ma (4.2-1.5 Ma, 95\% HPD), when the lineage from the Paraíba do Sul Basin (southern group) split from the lineage from the Northeastern Atlantic Forest (northern group) (Figure 3). Within the H. copelandii, analyses found the divergence between the H. copelandii from Jucuruçu and those from Doce + Mucuri in the Middle Pleistocene at approximately $0.5 \mathrm{Ma}(1.2-0.1 \mathrm{Ma}, 95 \% \mathrm{HPD})$, and the divergence between those from Doce and Mucuri occurring in the Middle/Late Pleistocene at approximately $0.16 \mathrm{Ma}(0.4-0.002 \mathrm{Ma}, 95 \% \mathrm{HPD})$. 


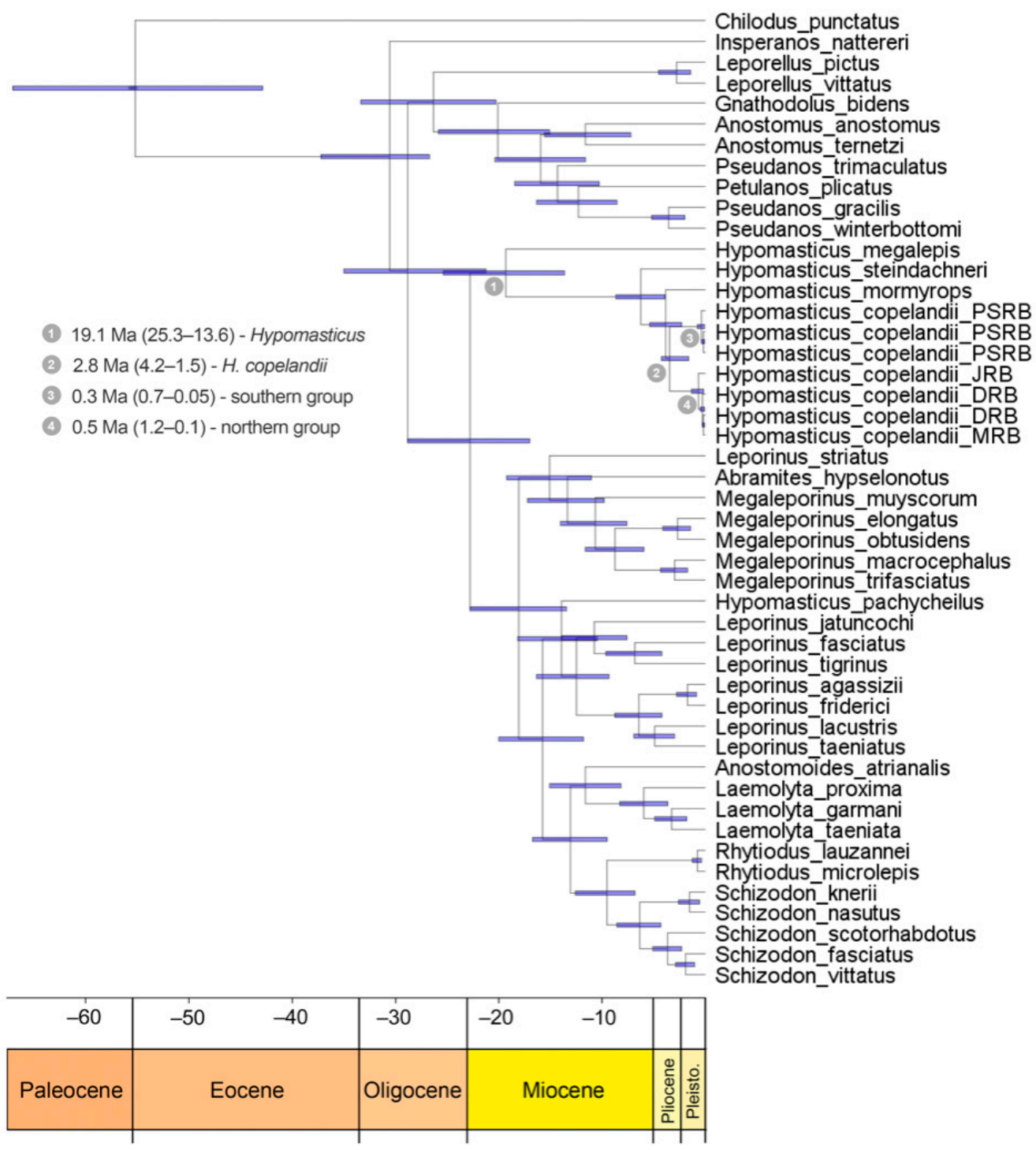

Figure 3. Time-calibrated phylogeny of Anostomidae highlighting the subgroups of Hypomasticus copelandii obtained from a relaxed clock analysis. Horizontal node bars indicate dating estimations with $95 \%$ posterior probability densities (HPD). Numbered gray circles represent important cladogenetic events discussed in the text. $\mathrm{DRB}=$ Doce River Basin; JRB = Jucuruçu River Basin; MRB = Mucuri River Basin; PRSB = Paraíba do Sul River Basin.

\section{Discussion}

Using mitochondrial and nuclear gene sequences, we provide a phylogenetic analysis for Hypomasticus copelandii comprising specimens distributed across four major river basins along the ecoregions of the Brazilian Atlantic coast. Our phylogenetic and species delimitation analyses reveal the existence of two genetic components within the $H$. copelandii: the first with specimens of the Doce, Mucuri and Jucuruçu rivers (the northern group) and the second with specimens from the Paraíba do Sul Basin (the southern group) (Figure 2). This result supports the morphological hypothesis for the existence of additional taxa inside H. copelandii [45] that merits formal taxonomic description. The fact that $H$. copelandii was described based on syntypes from multiple coastal rivers [45,46], including the rivers analyzed herein, makes the taxonomic investigation more complex. The future taxonomic study should analyze the type series and choose a lectotype either from the Paraíba do Sul Basin or from northern rivers with the others becoming paralectotypes.

The discovery of distinct genetic lineages within taxonomically-complex species is always intriguing but not surprising for Anostomidae. A recent macroevolution study of 
Characiformes detected a shift to higher speciation rates at the base of the Anostomidae that may have contributed to high levels of modern species diversity in the family [5]. This is also supported by extreme phenotypic plasticity that may have potentialized family speciation processes [81]. Indeed, molecular investigations have found several independent lineages inside Megaleporinus conirostris, M. macrocephalus, M. obtusidens, M. piavussu, M. trifasciatus [38], Laemolyta taeniata [33], Schizodon nasutus, S. vittatus [82], and within the Leporinus desmotes and L. friderici complexes [34,83]. Another independent lineage is H. pachycheilus from southern tributaries of the Amazon, obtained as closer to other species of Leporinus [22,38,45] in need of further investigation. Additionally, an integrative study provided genetic and morphological evidence for describing a new Hypomasticus from the Contas River system, eastern Brazil [45]. Our results highlight the existence of one more lineage within Hypomasticus and further genetic research might focus on the remaining species of the genus.

A taxonomy-based biogeographic analysis of freshwater fishes from the Northeastern Atlantic Rainforest drainages proposed the existence of two main groups: The North Group and Central-South Group [84]. The authors state that the drainages of the Central-South Group, which includes Doce and Mucuri basins, present some closely related species with the Paraíba do Sul ecoregion. The phylogeny of the armored catfish genus Pogonopoma indicated that $P$. wertheimeri, an endemic of the Doce, Mucuri, and São Mateus basins is the sister group of P. parahybae endemic of the Paraíba do Sul Basin [85]. Accordingly, a phylogeographic study of Hoplias malabaricus detected multiple genetic lineages along coastal rivers of eastern Brazil [86]. The northern/southern group pattern has been recurrent in the literature as shown in some molecular phylogenetic reconstructions for other clades of Neotropical freshwater fishes, such as in Geophagus [87] and Oligosarcus [88]. In Anostomidae, the molecular phylogeny of Megaleporinus also revealed two subclades of M. conirostris, one for the Doce River and another for the Paraíba do Sul [38]. Therefore, the evidence for the two geographically-structured subgroups of $H$. copelandii and these abovementioned examples allow us to propose a biogeographic hypothesis herein, in which the Paraíba do Sul Basin potentially contains a genetically distinct ichthyofauna compared to the northern drainages of the Doce, Mucuri, and Jucuruçu basins.

While the mitochondrial loci separated the Paraíba do Sul Basin from all the other northern drainages, the $S 7$ nuclear gene clustered Paraíba do Sul with the Doce Basin and segregated them from the Mucuri and Jucuruçu cluster in the species delimitation analyses (Figures 2d and S6). This mito-nuclear discordance has been explained because mitochondrial and nuclear genomes show intrinsic differences in inheritance and biology [89]. Additionally, they may have different evolutionary histories resulting from non-neutral processes [90], such as genetic drift, distinct selective pressures on different populations, introgression, incomplete lineage sorting, or horizontal gene transfer [91]. Moreover, most groups presenting the mito-nuclear discordance pattern have been isolated for long periods and are either in current secondary contact or have experienced range contact at some point in their past [92]. Therefore, the clustering of $H$. copelandii from the neighboring Doce and Paraíba do Sul basins by S7 is likely a reflection of a more recent contact between these two populations, while the clustering pattern observed using mitochondrial markers represents a more ancient history (Figure 2).

Past connections between coastal rivers of the Northeastern Atlantic Forest ecoregion have previously correlated with several fish species' distributional patterns [84,93]. These inventory studies clustered the Doce, Mucuri, and Jucuruçu basins in the same biogeographic group, and found that the Doce and Mucuri are closer to each other than to any other basin [84]. Recent paleogeographic reconstructions predict that currently isolated rivers of southeast South America were likely connected by paleodrainages during the Pleistocene [10]. However, current evidence does not indicate a paleo-connection between the proto-Doce and proto-Paraíba do Sul basins [10]. An alternative hypothesis is that the Neotropical ichthyofauna of the south-southeastern margin of the Brazilian Shield has experienced multiple headwater/river exchange events known as river captures since the 
Neogene, i.e., after $23 \mathrm{Ma}[6,94-96]$. Our time-calibrated tree evidenced that the split between H. copelandii from the Northeastern Atlantic Forest (Doce, Mucuri, and Jucuruçu) and Paraíba do Sul ecoregions was dated to the Plio-Pleistocene at around 2.8 Ma (4.2-1.5 Ma, 95\% HPD) (Figure 3). This event may have happened by allopatric speciation mediated by putative events of river capture between the Paraiba do Sul and the northernmost coastal drainages. Furthermore, the haplotypes shared between specimens from Doce and Mucuri also support the hypothesis of past river capture events among those river systems (Figure 2).

Our results reveal a hidden biodiversity within Hypomasticus copelandii and endorse a taxonomic review for the species group. Moreover, our phylogenetic analyses highlight the importance of Plio-Pleistocene headwater captures driving species diversification along coastal Atlantic rivers. The evidence for a hidden diversity allows a better management of the Neotropical ichthyofauna inhabiting highly degraded basins, impacted by pollution, mining activities, habitat fragmentation, and invasive species. Populations of Hypomasticus usually inhabit major river channels and rapids of the Neotropics [37], where severe anthropogenic activity has affected the natural resources [45]. The northern genetic lineage from the Doce River was recently affected by the vast dam breach of Mariana [12,49], and the discovery of these previously unrecognized lineages might help future management plans for freshwater fish conservation. For instance, the captive breeding and restocking actions aimed to supplement the Doce River ichthyofauna should use the "northern lineage" and avoid fish from captive breeding programs from the Paraíba do Sul Basin. Such distinct management may avoid outbreeding depression and the introduction of a possible new species by restocking actions.

Supplementary Materials: The following are available online at https://www.mdpi.com/article/ 10.3390/d14010029/s1, In the Supplementary Materials we include the Partition Finder results with the settings used and best partitioning scheme retrieved. Figure S1: Neighbor-joining tree for COI gene summarizing the relationships among Hypomasticus copelandii lineages. Numbers at nodes represent percentage bootstrap values obtained from 1000 samplings. Colors follow the map in Figure 2. Figure S2: Neighbor-joining tree for $12 \mathrm{~S}$ summarizing the relationships among Hypomasticus copelandii lineages. Numbers at nodes represent percentage bootstrap values obtained from 1000 samplings. Colors follow the map in Figure 2. Figure S3: Neighbor-joining tree for S7 summarizing the relationships among Hypomasticus copelandii lineages. Numbers at nodes represent percentage bootstrap values obtained from 1000 samplings. Colors follow the map in Figure 2. Figure S4: Maximum likelihood tree for COI summarizing the relationships among Hypomasticus copelandii lineages. The percentage of bootstrap replicates (out of 1000) that supported each node are shown. Colors follow the map in Figure 2. Figure S5: Maximum likelihood tree for $12 \mathrm{~S}$ summarizing the relationships among major lineages of Hypomasticus copelandii. The percentage of bootstrap replicates (out of 1000) that supported each node are shown. Colors follow the map in Figure 2. Figure S6: Maximum likelihood tree for S7 summarizing the relationships among major lineages of Hypomasticus copelandii. The percentage of bootstrap replicates (out of 1000) that supported each node are shown. Colors follow the map in Figure 2.

Author Contributions: Conceptualization, I.S.M. and D.C.C.; methodology, I.S.M. and J.S.D.; validation, I.S.M., J.S.D. and D.C.C.; formal analysis, I.S.M., B.F.M. and J.S.D.; investigation, I.S.M., B.F.M., J.S.D. and D.C.C.; resources, D.C.C.; data curation, I.S.M., B.F.M., J.S.D. and D.C.C.; writing-I.S.M. and D.C.C.; writing—review and editing, I.S.M., B.F.M., J.S.D., D.F.T. and D.C.C.; supervision, D.C.C.; project administration, D.C.C.; funding acquisition, D.C.C. All authors have read and agreed to the published version of the manuscript.

Funding: This research was funded by FAPESP grant number 16/11313-8, CNPq grant number 404991/2018-1, CNPq grant number 200159/2020-8, Stiassny AMNH Axelrod Research Curatorship, and Biocev Projetos Inteligentes. DCC is grateful to CNPq productivity fellowship 306155/2018-4.

Institutional Review Board Statement: The study was conducted according to the guidelines of the SISBIO permit No 37298-1. 
Data Availability Statement: The sequences obtained during this research were deposited in GenBank under the accession codes MK770202-MK770236, MH187578-MH187599, MF850381-MF850398 and MT427917.

Acknowledgments: We thank T. Pessali and A. Nobile for fish photographs in Figure 1. Parts of the analyses were conducted on Brycon/Zungaro servers at LBP/UNESP funded by FAPESP 14/26508-3 and on Edna server at PUC Minas funded by CEMIG P\&D GT 0635.

Conflicts of Interest: The authors declare no conflict of interest.

\section{References}

1. Albert, J.S.; Reis, R.E. Historical Biogeography of Neotropical Freshwater Fishes; University of California Press: Oakland, CA, USA, 2011; p. 388.

2. Albert, J.S.; Tagliacollo, V.A.; Dagosta, F. Diversification of neotropical freshwater fishes. Annu. Rev. Ecol. Evol. Syst. 2020, 51, 27-53. [CrossRef]

3. Hubert, N.; Duponchelle, F.; Nuñez, J.; Rivera, R.; Bonhomme, F.; Renno, J.F. Isolation by distance and Pleistocene expansion of the lowland populations of the white piranha Serrasalmus rhombeus. Mol. Ecol. 2007, 16, 2488-2503. [CrossRef]

4. $\quad$ Lundberg, J.G.; Marshall, L.G.; Guerrero, J.; Horton, B.K.; Malabarba, M.C.; Wesselingh, F. The stage for Neotropical fish diversification: A history of tropical South American rivers. In Phylogeny and Classification of Neotropical Fishes; Malabarba, L.R., Reis, R.E., Vari, R.P., Lucena, Z.M.S., Lucena, C.A.S., Eds.; Edipucrs: Porto Alegre, Brazil, 1998; pp. $13-48$.

5. Melo, B.F.; Sidlauskas, B.L.; Near, T.J.; Roxo, F.F.; Ghezelayagh, A.; Ochoa, L.E.; Stiassny, M.L.J.; Arroyave, J.; Chang, J.; Faircloth, B.C.; et al. Accelerated diversification explains the exceptional species richness of Tropical characoid fishes. Syst. Biol. 2021. [CrossRef]

6. Ribeiro, A.C. Tectonic history and the biogeography of the freshwater fishes from the coastal drainages of eastern Brazil: An example of faunal evolution associated with a divergent continental margin. Neotrop. Ichthyol. 2006, 4, 225-246. [CrossRef]

7. Ruokolainen, K.; Moulatlet, G.M.; Zuquim, G.; Hoorn, C.; Tuomisto, H. Geologically recent rearrangements in central Amazonian river network and their importance for the riverine barrier hypothesis. Front. Biogeogr. 2019, 11, e45046e. [CrossRef]

8. Thomaz, A.T.; Malabarba, L.R.; Bonatto, S.L.; Knowles, L.L. Testing the effect of palaeodrainages versus habitat stability on genetic divergence in riverine systems: Study of a Neotropical fish of the Brazilian coastal Atlantic Forest. J. Biogeogr. 2015, 42, 2389-2401. [CrossRef]

9. Thomaz, A. Riverscape Genetics: Insights into the Drivers of Divergence in Coastal Brazilian Fishes. Ph.D. Thesis, University of Michigan, Ann Harbor, MI, USA, 2017.

10. Thomaz, A.T.; Lacey Knowles, L. Flowing into the unknown: Inferred paleodrainages for studying the ichthyofauna of brazilian coastal rivers. Neotrop. Ichthyol. 2018, 16, e180019. [CrossRef]

11. Dagosta, F.C.P.; de Pinna, M.; Peres, C.A.; Tagliacollo, V.A. Existing protected areas provide a poor safety-net for threatened Amazonian fish species. Aquat. Conserv. Mar. Freshw. Ecosyst. 2020, 31, 1167-1189. [CrossRef]

12. Fernandes, G.W.; Goulart, F.F.; Ranieri, B.D.; Coelho, M.S.; Dales, K.; Boesche, N.; Bustamante, M.; Carvalho, F.A.; Carvalho, D.C.; Dirzo, R.; et al. Deep into the mud: Ecological and socio-economic impacts of the dam breach in Mariana, Brazil. Nat. Conserv. 2016, 14, 35-45. [CrossRef]

13. Ota, R.R.; Message, H.J.; da Graça, W.J.; Pavanelli, C.S. Neotropical Siluriformes as a model for insights on determining biodiversity of animal groups. PLoS ONE 2015, 10, e0132913. [CrossRef]

14. Reis, R.E.; Albert, J.S.; Di Dario, F.; Mincarone, M.M.; Petry, P.; Rocha, L.A. Fish biodiversity and conservation in South America. J. Fish Biol. 2016, 89, 12-47. [CrossRef]

15. Melo, B.F.; Ochoa, L.E.; Vari, R.P.; Oliveira, C. Cryptic species in the Neotropical fish genus Curimatopsis (Teleostei, Characiformes). Zool. Scr. 2016, 45, 650-658. [CrossRef]

16. Ochoa, L.E.; Melo, B.F.; García-Melo, J.E.; Maldonado-Ocampo, J.A.; Souza, C.S.; Albornoz-Garzón, J.G.; Conde-Saldaña, C.C.; Villa-Navarro, F.; Ortega-Lara, A.; Oliveira, C. Species delimitation reveals an underestimated diversity of Andean catfishes of the family Astroblepidae (Teleostei: Siluriformes). Neotrop. Ichthyol. 2020, 18, 1-19. [CrossRef]

17. Britz, R.; Hundsdörfer, A.; Fritz, U. Funding, training, permits-The three big challenges of taxonomy. Megataxa 2020, 1, 49-52. [CrossRef]

18. Ely, C.V.; Bordignon, S.A.d.L.; Trevisan, R.; Boldrini, I.I. Implications of poor taxonomy in conservation. J. Nat. Conserv. 2017, 36, 10-13.

19. Pereira, L.H.G.; Maia, G.M.G.; Hanner, R.; Foresti, F.; Oliveira, C. DNA barcodes discriminate freshwater fishes from the Paraíba do sul River Basin, São Paulo, Brazil. Mitochondrial Dna 2011, 22 (Suppl. 1), 71-79. [CrossRef]

20. Pereira, L.H.G.; Hanner, R.; Foresti, F.; Oliveira, C. Can DNA barcoding accurately discriminate megadiverse Neotropical freshwater fish fauna? BMC Genet. 2013, 14, 20. [CrossRef]

21. Calegari, B.B.; Vari, R.P.; Reis, R.E. Phylogenetic systematics of the driftwood catfishes (Siluriformes: Auchenipteridae): A combined morphological and molecular analysis. Zool. J. Linn. Soc. 2019, 187, 661-773. [CrossRef]

22. Ramirez, J.L.; Carvalho-Costa, L.F.; Venere, P.C.; Carvalho, D.C.; Troy, W.P.; Galetti, P.M. Testing monophyly of the freshwater fish Leporinus (Characiformes, Anostomidae) through molecular analysis. J. Fish Biol. 2016, 88, 1204-1214. [CrossRef] 
23. Silva, G.S.C.; Melo, B.F.; Oliveira, C.; Benine, R.C. Revision of the South American genus Tetragonopterus Cuvier, 1816 (Teleostei: Characidae) with description of four new species. Zootaxa 2016, 4200, 1-46. [CrossRef]

24. Hebert, P.D.N.; Cywinska, A.; Ball, S.L.; DeWaard, J.R. Biological identifications through DNA barcodes. Proc. R. Soc. B Biol. Sci. 2003, 270, 313-321. [CrossRef]

25. Machado, V.N.; Collins, R.A.; Ota, R.P.; Andrade, M.C.; Farias, I.P.; Hrbek, T. One thousand DNA barcodes of piranhas and pacus reveal geographic structure and unrecognised diversity in the Amazon. Sci. Rep. 2018, 8, 8387. [CrossRef]

26. Rossini, B.C.; Oliveira, C.A.M.; de Melo, F.A.G.; de Araújo Bertaco, V.; de Astarloa, J.M.D.; Rosso, J.J.; Foresti, F.; Oliveira, C. Highlighting Astyanax species diversity through DNA Barcoding. PLoS ONE 2016, 11, e0167203. [CrossRef]

27. Britski, H.A.; Melo, B.F.; Vari, R.P.; Oliveira, C. Revalidation and redescription of Steindachnerina nigrotaenia and redescription of S. insculpta (Characiformes: Curimatidae). Neotrop. Ichthyol. 2019, 17, e180076. [CrossRef]

28. Carvalho, D.C.; Oliveira, D.A.A.; Beheregaray, L.B.; Torres, R.A. Hidden genetic diversity and distinct evolutionarily significant units in an commercially important Neotropical apex predator, the catfish Pseudoplatystoma corruscans. Conserv. Genet. 2012, 13, 1671-1675. [CrossRef]

29. Pires, A.A.; Ramirez, J.L.; Galetti, P.M., Jr.; Troy, W.P.; Freitas, P.D. Molecular analysis reveals hidden diversity in Zungaro (Siluriformes: Pimelodidade): A genus of giant South American catfish. Genetica 2017, 145, 335-340. [CrossRef]

30. Ramirez, J.L.; Birindelli, J.L.; Carvalho, D.C.; Affonso, P.R.A.M.; Venere, P.C.; Ortega, H.; Carrillo-Avila, M.; Rodríguez-Pulido, J.A.; Galetti, P.M., Jr. Revealing hidden diversity of the underestimated Neotropical ichthyofauna: DNA Barcoding in the recently described genus Megaleporinus (Characiformes: Anostomidae). Front. Genet. 2017, 8, 149. [CrossRef]

31. Gomes, L.C.; Pessali, T.C.; Sales, N.G.; Pompeu, P.S.; Carvalho, D.C. Integrative taxonomy detects cryptic and overlooked fish species in a neotropical river basin. Genetica 2015, 143, 581-588. [CrossRef]

32. Pugedo, M.L.; de Andrade Neto, F.R.; Pessali, T.C.; Birindelli, J.L.O.; Carvalho, D.C. Integrative taxonomy supports new candidate fish species in a poorly studied neotropical region: The Jequitinhonha River Basin. Genetica 2016, 144, 341-349. [CrossRef]

33. Ramirez, J.L.; Galetti, P.M., Jr. DNA barcode and evolutionary relationship within Laemolyta Cope 1872 (Characiformes: Anostomidae) through molecular analyses. Mol. Phylogenet. Evol. 2015, 93, 77-82. [CrossRef]

34. Silva-Santos, R.; Ramirez, J.L.; Galetti, P.M., Jr.; Freitas, P.D. Molecular evidences of a hidden complex scenario in Leporinus cf. friderici. Front. Genet. 2018, 9, 47. [CrossRef] [PubMed]

35. Fricke, R.; Eschmeyer, W.N.; Fong, J.D. CAS—Eschmeyer's Catalog of Fishes—Genera/Species by Family/Subfamily. Available online: https:/ / researcharchive.calacademy.org/research/ichthyology/catalog/SpeciesByFamily.asp (accessed on 24 June 2020).

36. Garavello, J.C.; Britski, H.A. Family Anostomidae (Headstanders). Check List Freshw. Fishes South Cent. Am. 2003, 1, 71-84.

37. Sidlauskas, B.L.; Birindelli, J.L.O. Family Anostomidae-toothed headstanders. In Field Guide to the Fishes of the Amazon, Orinoco $\mathcal{E}$ Guianas; Princeton University Press: Princeton, NJ, USA, 2017; pp. 82-89.

38. Ramirez, J.L.; Birindelli, J.L.O.; Galetti, P.M. A new genus of Anostomidae (Ostariophysi: Characiformes): Diversity, phylogeny and biogeography based on cytogenetic, molecular and morphological data. Mol. Phylogenet. Evol. 2017, 107, 308-323. [CrossRef]

39. Sidlauskas, B.L.; Assega, F.M.; Melo, B.F.; Oliveira, C.; Birindelli, J.L.O. Total evidence phylogenetic analysis reveals polyphyly of Anostomoides and uncovers an unexpectedly ancient genus of Anostomidae fishes (Characiformes). Zool. J. Linn. Soc. 2021. [CrossRef]

40. Sidlauskas, B.L.; Vari, R.P. Phylogenetic relationships within the South American fish family Anostomidae (Teleostei, Ostariophysi, Characiformes). Zool. J. Linn. Soc. 2008, 154, 70-210. [CrossRef]

41. Burns, M.D.; Frable, B.W.; Sidlauskas, B.L. A new species of Leporinus (Characiformes: Anostomidae), from the Orinoco Basin, Venezuela. Copeia 2014, 2014, 206-214. [CrossRef]

42. Britski, H.A.; Garavello, J.C. Sobre Leporinus octofasciatus Steindachner da bacia do Paraná (Pisces, Anostomidae). Papéis Avulsos Zool. 1978, 31, 237-250.

43. Garavello, J.C.; Britski, H.A. Revisão Taxonomica do Gênero Leporinus Spix, 1829 (Ostariophysi, Anostomidae); Universidade de São Paulo: São Paulo, Brazil, 1979.

44. Sidlauskas, B. Testing for unequal rates of morphological diversification in the absence of a detailed phylogeny: A case study from Characiform fishes. Evolution 2007, 61, 299-316. [CrossRef]

45. Birindelli, J.L.O.; Melo, B.F.; Ribeiro-Silva, L.R.; Diniz, D.; Oliveira, C. A new species of Hypomasticus from Eastern Brazil based on morphological and molecular data (Characiformes, Anostomidae). Copeia 2020, 108, 416-425. [CrossRef]

46. Steindachner, F. Die Süsswasserfische des südöstlichen Brasilien (II). Sitzungsberichte der Kaiserlichen Akademie der Wissenschaften. Math. Nat. Cl. 1875, 71, 211-245.

47. Costa, A.P.R. Aspectos da biologia reprodutiva de fêmeas do Piau-vermelho Leporinus copelandii Steindachner, 1875 (Pisces, Anostomidae), na bacia do Baixo Rio Paraíba do Sul (RJ). Master's Thesis, Centro de Ciências e Tecnologia Agropecuárias, Universidade Estadual do Norte Fluminense Darcy Ribeiro, Campos de Goytacazes, Brazil, 1999.

48. Abell, R.; Thieme, M.L.; Revenga, C.; Bryer, M.; Kottelat, M.; Bogutskaya, N.; Coad, B.; Mandrak, N.; Balderas, S.C.; Bussing, W.; et al. Freshwater ecoregions of the world: A new map of biogeographic units for freshwater biodiversity conservation. BioScience 2008, 58, 403-414. [CrossRef]

49. Escobar, H. Mud tsunami wreaks ecological havoc in Brazil. Science 2015, 350, 1138-1139. [CrossRef] [PubMed]

50. Garcia, L.C.; Ribeiro, D.B.; Roque, F.d.O.; Ochoa-Quintero, J.M.; Laurance, W.F. Brazil's worst mining disaster: Corporations must be compelled to pay the actual environmental costs. Ecol. Appl. 2017, 27, 5-9. [CrossRef] [PubMed] 
51. Gomes, L.E.d.O.; Correa, L.B.; Sá, F.; Neto, R.R.; Bernardino, A.F. The impacts of the Samarco mine tailing spill on the Rio Doce estuary, Eastern Brazil. Mar. Pollut. Bull. 2017, 120, 28-36. [CrossRef]

52. Sarmento-Soares, L.M.; Rodrigues, L.N.; Martins-Pinheiro, R.F. Peixes do rio Doce segundo as coleções. Bol. Soc. Bras. Ictiol. 2017, 123, 9-25.

53. Aljanabi, S.M.; Martinez, I. Universal and rapid salt-extraction of high quality genomic DNA for PCR-based techniques. Nucleic Acids Res. 1997, 25, 4692-4693. [CrossRef]

54. Ivanova, N.V.; Zemlak, T.S.; Hanner, R.H.; Hebert, P.D.N. Universal primer cocktails for fish DNA barcoding. Mol. Ecol. Notes 2007, 7, 544-548. [CrossRef]

55. Thomsen, P.F.; Møller, P.R.; Sigsgaard, E.E.; Knudsen, S.W.; Jørgensen, O.A.; Willerslev, E. Environmental DNA from seawater samples correlate with trawl catches of subarctic, deepwater fishes. PLoS ONE 2016, 11, e0165252. [CrossRef]

56. Chow, S.; Hazama, K. Universal PCR primers for S7 ribosomal protein gene introns in fish. Mol. Ecol. 1998, 7, 1255-1256. [PubMed]

57. Ratnasingham, S.; Hebert, P.D.N. Bold: The Barcode of Life Data System (http://www.barcodinglife.org). Mol. Ecol. Notes 2007, 7, 355-364. [CrossRef]

58. Thompson, J.D.; Higgins, D.G.; Gibson, T.J. CLUSTAL W: Improving the sensitivity of progressive multiple sequence alignment through sequence weighting, position-specific gap penalties and weight matrix choice. Nucleic Acids Res. 1994, 22, 4673-4680. [CrossRef] [PubMed]

59. Kumar, S.; Stecher, G.; Tamura, K. MEGA7: Molecular Evolutionary Genetics Analysis Version 7.0 for Bigger Datasets. Mol. Biol. Evol. 2016, 33, 1870-1874. [CrossRef] [PubMed]

60. Xia, X. DAMBE5: A comprehensive software package for Data Analysis in Molecular Biology and Evolution. Mol. Biol. Evol. 2013, 30, 1720-1728. [CrossRef]

61. Darriba, D.; Taboada, G.L.; Doallo, R.; Posada, D. jModelTest 2: More models, new heuristics and parallel computing. Nat. Methods 2012, 9, 772. [CrossRef] [PubMed]

62. Guindon, S.; Gascuel, O. A simple, fast, and accurate algorithm to estimate large phylogenies by maximum likelihood. Syst. Biol. 2003, 52, 696-704. [CrossRef] [PubMed]

63. Miller, M.A.; Pfeiffer, W.; Schwartz, T. Creating the CIPRES Science Gateway for inference of large phylogenetic trees. In Proceedings of the 2010 Gateway Computing Environments Workshop (GCE) Institute of Electrical and Electronics Engineers, New Orleans, LA, USA, 14 November 2010.

64. Stamatakis, A. RAxML-VI-HPC: Maximum likelihood-based phylogenetic analyses with thousands of taxa and mixed models. Bioinformatics 2021, 22, 2688-2690. [CrossRef]

65. Fujisawa, T.; Barraclough, T.G. Delimiting species using single-locus data and the Generalized Mixed Yule Coalescent approach: A revised method and evaluation on simulated data sets. Syst. Biol. 2013, 62, 707-724. [CrossRef] [PubMed]

66. Zhang, J.; Kapli, P.; Pavlidis, P.; Stamatakis, A. A general species delimitation method with applications to phylogenetic placements. Bioinformatics 2013, 29, 2869-2876. [CrossRef]

67. Puillandre, N.; Lambert, A.; Brouillet, S.; Achaz, G. ABGD, Automatic Barcode Gap Discovery for primary species delimitation. Mol. Ecol. 2012, 21, 1864-1877. [CrossRef]

68. Ward, R.D. DNA barcode divergence among species and genera of birds and fishes. Mol. Ecol. Resour. 2009, 9, 1077-1085. [CrossRef]

69. Milan, D.T.; Mendes, I.S.; Damasceno, J.S.; Teixeira, D.F.; Sales, N.G.; Carvalho, D.C. New 12 S metabarcoding primers for enhanced Neotropical freshwater fish biodiversity assessment. Sci. Rep. 2020, 10, 17966. [CrossRef]

70. Brown, S.D.J.; Collins, R.A.; Boyer, S.; Lefort, M.-C.; Malumbres-Olarte, J.; Vink, C.J.; Cruickshank, R.H. Spider: An R package for the analysis of species identity and evolution, with particular reference to DNA barcoding-BROWN-2012—Molecular Ecology Resources-Wiley Online Library. Mol. Ecol. Resour. 2012, 12, 562-565. [CrossRef] [PubMed]

71. Team, R.C. R: A Language and Environment for Statistical Computing. 2013. Available online: http://r.meteo.uni.wroc.pl/web/ packages/dplR/vignettes/intro-dplR.pdf (accessed on 24 June 2020).

72. Drummond, A.J.; Rambaut, A. BEAST: Bayesian evolutionary analysis by sampling trees. BMC Evol. Biol. 2007, 7, 1-8. [CrossRef]

73. Rambaut, A.; Drummond, A.J.; Xie, D.; Baele, G.; Suchard, M.A. Posterior Summarization in Bayesian Phylogenetics Using Tracer 1.7. Syst. Biol. 2018, 67, 901-904. [CrossRef] [PubMed]

74. Drummond, A.J.; Suchard, M.A.; Xie, D.; Rambaut, A. Bayesian phylogenetics with BEAUti and the BEAST 1.7. Mol. Biol. Evol. 2012, 29, 1969-1973. [CrossRef] [PubMed]

75. Lanfear, R.; Calcott, B.; Ho, S.Y.W.; Guindon, S. PartitionFinder: Combined selection of partitioning schemes and substitution models for phylogenetic analyses. Mol. Biol. Evol. 2012, 29, 1695-1701. [CrossRef] [PubMed]

76. Bouckaert, R.; Heled, J.; Kühnert, D.; Vaughan, T.; Wu, C.H.; Xie, D.; Suchard, M.A.; Rambaut, A.; Drummond, A.J. BEAST 2: A Software Platform for Bayesian Evolutionary Analysis. PLoS Comput. Biol. 2014, 10, e1003537. [CrossRef]

77. Ameghino, F. Sur l'Arrhinolemur, mammifére aberrant du tertiare du Paraná. Comptes Rendus L'académie Sci. 1898, 127, 395-396.

78. Bogan, S.; Sidlauskas, B.; Vari, R.P.; Agnolin, F. Arrhinolemur scalabrinii Ameghino, 1898, of the late Miocene: A taxonomic journey from the Mammalia to the Anostomidae (Ostariophysi: Characiformes). Neotrop. Ichthyol. 2021, 10, 555-560. [CrossRef]

79. Günther, A. Diagnoses of some new freshwater fishes from Surinam and Brazil, in the collection of the British Museum. J. Nat. Hist. 1868, 1, 475-481. [CrossRef] 
80. Kner, R. Beiträge zur Familie der Characinen. Sitzungsberichte der Kaiserlichen Akademie der Wissenschaften. Math. Nat. Cl. 1858, 30, 75-80.

81. Lofeu, L.; Anelli, V.; Straker, L.C.; Kohlsdorf, T. Developmental plasticity reveals hidden fish phenotypes and enables morphospace diversification. Evolution 2021, 75, 1170-1188. [CrossRef]

82. Ramirez, J.L.; Santos, C.A.; Machado, C.B.; Oliveira, A.K.; Garavello, J.C.; Britski, A.H.; Galetti, P.M., Jr. Molecular phylogeny and species delimitation of the genus Schizodon (Characiformes, Anostomidae). Mol. Phylogenetics Evol. 2020, 153, 106959. [CrossRef] [PubMed]

83. Burns, M.D.; Chatfield, M.; Birindelli, J.L.O.; Sidlauskas, B.L. Systematic assessment of the Leporinus desmotes species complex, with a description of two new species. Neotrop. Ichthyol. 2017, 15, e160166. [CrossRef]

84. Camelier, P.; Zanata, A.M. Biogeography of freshwater fishes from the Northeastern Mata Atlântica freshwater ecoregion: Distribution, endemism, and area relationships. Neotrop. Ichthyol. 2015, 12, 683-698. [CrossRef]

85. Quevedo, R.; Reis, R.E. Pogonopoma obscurum: A new species of Loricariid catfish (Siluriformes: Loricariidae) from Southern Brazil, with comments on the genus Pogonopoma. Copeia 2002, 2002, 402-410. [CrossRef]

86. Pereira, T.L.; Santos, U.; Schaefer, C.E.; Souza, G.O.; Paiva, S.R.; Malabarba, L.R.; Schmidt, E.E.; Dergam, J.A. Dispersal and vicariance of Hoplias malabaricus (Bloch, 1794) (Teleostei, Erythrinidae) populations of the Brazilian continental margin. J. Biogeogr. 2013, 40, 905-914. [CrossRef]

87. Argolo, L.A.; López-Fernández, H.; Batalha-Filho, H.; de Mello Affonso, P.R.A. Unraveling the systematics and evolution of the 'Geophagus' brasiliensis (Cichliformes: Cichlidae) species complex. Mol. Phylogenet. Evol. 2020, 50, 106855. [CrossRef] [PubMed]

88. Wendt, E.W.; Silva, P.C.; Malabarba, L.R.; Carvalho, T.P. Phylogenetic relationships and historical biogeography of Oligosarcus (Teleostei: Characidae): Examining riverine landscape evolution in southeastern South America. Mol. Phylogenetics Evol. 2019, 140, 106604. [CrossRef]

89. Avise, J.C. Mitochondrial DNA and the evolutionary genetics of higher animals. Philos. Transact. R. Soc. Lond. Ser. B Biol. Sci. 1986, 312, 325-342.

90. Gompert, Z.; Forister, M.L.; Fordyce, J.A.; Nice, C.C. Widespread mito-nuclear discordance with evidence for introgressive hybridization and selective sweeps in Lycaeides. Mol. Ecol. 2008, 17, 5231-5244. [CrossRef]

91. Ivanov, V.; Lee, K.M.; Mutanen, M. Mitonuclear discordance in wolf spiders: Genomic evidence for species integrity and introgression. Mol. Ecol. 2018, 27, 1681-1695. [CrossRef] [PubMed]

92. Toews, D.P.; Brelsford, A. The biogeography of mitochondrial and nuclear discordance in animals. Mol. Ecol. 2012, 21, 3907-3930. [CrossRef]

93. Sarmento-Soares, L.M.; Martins-Pinheiro, R.F. Glanidium botocudo, a new species from the rio Doce and rio Mucuri, Minas Gerais, Brazil (Siluriformes: Auchenipteridae) with comments on taxonomic position of Glanidium bockmanni Sarmento-Soares \& Buckup. Neotrop. Ichthyol. 2013, 11, 265-274.

94. Roxo, F.F.; Silva, G.S.C.; Zawadzki, C.H.; Oliveira, C. Neoplecostomus doceensis: A new loricariid species (Teleostei, Siluriformes) from the rio doce basin and comments about its putative origin. ZooKeys 2014, 440, 115-127. [CrossRef] [PubMed]

95. Santos, R.P.; Melo, B.F.; Yazbeck, G.M.; Oliveira, R.S.; Hilário, H.O.; Prosdocimi, F.; Carvalho, D.C. Diversification of Prochilodus in the eastern Brazilian Shield: Evidence from complete mitochondrial genomes (Teleostei, Prochilodontidae). J. Zool. Syst. Evol. Res. 2021, 59, 1053-1063. [CrossRef]

96. Souza, C.S.; Silva, G.S.C.; Ochoa, L.E.; Roxo, F.F.; Costa-Silva, G.J.; Foresti, F.; Melo, B.F.; Oliveira, C. Molecular and morphological diversity in species of Kronichthys (Teleostei, Loricariidae) from Atlantic coastal rivers of Brazil. J. Fish Biol. 2021, 98, 668-679. [CrossRef] 